\title{
Thromboembolism in chronic Chagas' heart disease
}

\author{
Heart Institute of Marilia, Faculdade de Medicina de \\ Marília - São Paulo, Brazil
}

Thromboembolic episodes are particularly important in chronic Chagas' heart disease. Systemic and pulmonary embolic phenomena are important complications of the disease. Prophylaxis of the thromboembolic phenomena with anticoagulant therapy should be considered in several clinical forms of the disease. Further studies will have to address the stratification risk issue.

UNITERMS: Chagas's disease. Thromboembolism.

A ccording to the predominal clinical presentation, chagasic cardiopathy has been classified into: arrhythmias, cardiac failure and thromboembolic syndrome (24). Since the original description by Chagas, these types of presentation have been thoroughly related to the natural history of the disease's manifestation. Chagas' disease is a current issue in publications on systemic and pulmonary thromboembolism, particularly in the reports coming from geographic locations with a high prevalence of Chagas' disease $(7,21)$. In spite of the well-known importance of the thromboembolic phenomenon, reports and therapeutic guidelines on prophylaxis of such complications are scarce.

\section{ANATOMOPATHOLOGICAL FEATURES}

Thrombosis is commonly found in anatomopathological studies of chronic cardiopathy. The high incidence of mural thrombosis in chagasic cardiopathy has been related to ventricular dilatation and to myocardial dysfunction, resulting in slowness and stagnation of the blood flow. These are all associated with an inflammatory 
reaction of the subjacent myocardium and endocardium, thus favouring thrombosis.

In patients with congestive heart failure, thrombosis is more frequent in the right atrium. In patients with a normal ventricular function, thrombosis is more common in the left ventricle, specially associated with vortex lesion. It is believed that reduction in the speed of blood renovation, besides allowing a longer contact time between the blood components and the endothelium increases the chances of its utilization in the thrombogenic process. Reduction in the speed of blood renovation also submits the local endothelium to hypoxia, causing changes that may lead to thrombosis.

The inflammatory process responsible for the myocarditis that may affect the endocardium is also an important factor in the genesis of intracavity thrombi. The interaction between the complement and the kinin systems is triggered in the initial stages of the inflammatory activity, thus contributing in some way to thrombi formation.

Oliveira F et al. (10), on necropsy based studies, found apical thrombosis in the left ventricle in $36.8 \%$ of the chronic chagasic hearts they studied with a vortical lesion. Apical thrombosis was recorded in only $11.1 \%$ of the healthy hearts. Vortical lesion with spacing in the muscular bundles showed a lower frequency of thrombosis $(9 \%)$ when compared with the lesion characterised by the thinning of the muscular bundles without spacing $(58.1 \%)$. Likewise. Meira de Oliveira et al. (22) reported a relationship between heart weight and cardiac thrombosis. Heavier hearts presented a higher incidence of cardiac thrombosis when compared with lighter hearts. Out of 1,345 cases studied, 750 cases did not present cardiac thrombosis or thromboembolic phenomena. The remaining 595 cases $(44 \%)$ related to the following situations: 185 cases of cardiac thrombosis with no thromboembolic phenomena in the corresponding circulation; 245 cases with thromboembolic phenomena with no thrombosis in the heart chambers of the corresponding circulation; 165 cases with thromboembolic phenomena and thrombosis in the cardiac chamber of the corresponding circulation.

The arterial territories more frequently affected were: lung circulation in $36 \%$, kidneys in $36 \%$, spleen in $14 \%$, and brain in $10 \%$. A high incidence of thromboembolism was also recorded by Arteaga-Fernandez et al. (5). Out of 111 patients studied, $81(73 \%)$ had cardiac thrombosis, $53 \%$ in the right chambers and $46 \%$ in the left chambers.

Embolic events were recorded in $60 \%$ of the patients, being $65 \%$ pulmonary and $38 \%$ systemic, respectively. Among all the cases with thrombosis in the right chambers, 35 out of 65 patients $(53 \%)$ showed pulmonary embolism. On the other hand, among the cases with pulmonary embolism, 6 out of 41 cases (14\%) had no thrombosis in the right cardiac chambers. Among the cases of thrombosis in the left cardiac chambers, 24 out of 56 patients (42\%) presented systemic embolism, whereas among the cases of embolism, 2 out of 26 cases (7\%) did not present thrombosis in the left chambers.

\section{CLINICAL IMPLICATIONS}

The high incidence and extension of the thromboembolic phenomena recorded in necropsy studies is impressive even to a cardiologist dealing with patients with severe cardiopathy. Mortality due to these phenomena seems to be related, in most cases, to pulmonary and cerebral embolism and it is significantly higher in cases presenting more than one arterial territory affected by thromboembolism.

Regarding pulmonary embolism, contrary to what occurs in non-chagasic patients, it is assumed that most of these events originate from the heart and not from venous thrombosis of the lower limbs.

The presence of embolic cerebral strokes in chronic chagasic cardiopathy, originally described by Nussenzweig et al. (20), has a great clinical importance because it may cause death or severe sequelae. It should be pointed out that in the analysis of the eight cases originally described, the EKG was abnormal in all of them. Seven had congestive heart failure and five had a pulmonary infarct. Neiva and Andrade (19) recorded in 10 autopsies of chagasic patients with cerebral stroke, cardiac failure associated with the presence of left ventricle mural thrombus in eight cases. Silva et al. (27), recorded 12 cases of cerebral ischemic stroke in a series of chagasic cases. Out of these, $10 \mathrm{had}$ apical lesion and $4 \mathrm{had}$ thrombi. Sobral Neto et al. (29) recorded $8.23 \%$ of cerebral thromboembolism in 328 necropsy cases and $92.59 \%$ of these displayed apical lesion. The presence of kidney and mesenteric embolism, though frequent, had been the subject of more reports in anatomo-pathological studies. This is possible since these events cause fewer symptoms and consequently fewer complaints. Coronarioembolism leading to heart attacks, although infrequent, has been described in the chronic stages of Chagas' disease. Contrary to what occurs in other emboligenic cardiac disorders, embolism to the upper and lower limbs is relatively uncommon in chagasic cardiopathy.

Albanese Filho (1) recorded 55 patients suffering from chagasic apical lesion during a period from 19 to 
176 months and noticed 17 thromboembolic events in 14 patients $(24.45 \%)$. Most of these patients had heart failure and almost one-third had intracavity thrombus. Although thromboembolism may occur in different stages of the disease, some characteristics allow a definition of patients more susceptible to these events. (Table 1). The authors believe that these attempts to group patients are relevant to the discussion of the prophylactic and therapeutic features of these phenomena.

\section{Table I}

Subgroups of patients with a higher propensity to thromboembolic events in the Chagasic cardiopathy

1) Severe myocardial dysfunction

Functional class III and IV

Chronic visceral venous congestion

Cardiac dilation

EKG: Bundle blocks and hemiblocks

electrically inactive areas,

changes in the ventricular repolarization

Low ejection fraction in the echocardiogram

2) Atrial fibrillation

3) Apical lesion of the left ventricle

4) Presence of intracavity thrombus

5) Prior thromboembolic phenomenon

\section{INDICATION AND FEASIBILITY OF} ANTITHROMBOTIC THERAPY

The use of anticoagulants in the prevention and treatment of thromboembolic diseases, though unquestionable in some situations, it remains controversial in other situations. Two aspects have been exhaustively evaluated. One is the indication of anticoagulant medication based on the judgement of its beneficial effect or efficacy. Another equally aspect important is the feasibility of this type of therapy, especially the assessment of its side effects and safety. When prescribed to heart disease patients (non-chagasic in origin), the analysis of the combined results provided by the Veterans Affairs Vasodilator-Heart Failure Trials (V-HeFT I and II) showed that the use of Warfarin did not reduce the incidence of thromboembolic phenomena. The opposite was found with the use of platelet antiaggregants. Comparing the patients who received anticoagulants with the patients who received platelet antiaggregant medication, the latter showed a significant reduction in the occurrence rate of thromboembolic events. The use of antithrombotic therapy in patients with atrial fibrillation resulting from rheumatic valvular disease is already well established. However, although atrial fibrillation in patients with valvular disease is present in almost half of the 100,000 cases of ischemic cerebral stroke recorded annually in the US, the manner to prevent it is still a matter of debate. Several randomised prospective studies (AFASK, SPAF, BAATAF, CAFA) have been performed in the search for a definitive answer. The results with Warfarin have been repeatedly successful in reducing thromboembolism in these patients. Even in small doses, in an attempt to maintain the prothrombin time in the 1.2 to 1.5 range and the INR (International Normalized Ratio) in the 1.5 to 3.0 range, the drug was proven to be effective.

Regarding aspirin, the results have not been unanimous. Nevertheless, SPAF findings have been encouraging as to the use of a $325 \mathrm{mg}$ dose. Present data suggest that the benefits of chronic use of Warfarin in low doses outweigh the risks for most patients with atrial fibrillation as long as they are good candidates for oral anticoagulant therapy. Among these so-called good candidates, patients with chronic atrial fibrillation, older than 65 years, history of hypertension and presence of cardiac disease (mainly cardiac failure or coronary disease) would be included. Nevertheless, until more data are available, Aspirin $(325 \mathrm{mg}$ ) should be considered for patients who are not good candidates (less than 60 years with paroxysmal or isolated atrial fibrillation) or who are unwilling to receive anticoagulant therapy.

Future alternatives to be assessed will include treatment regimens with even lower doses of Warfarin or a combination of very low doses of Warfarin and Aspirin.

Fuster et al. (11) in a study with patients with idiopathic dilated cardiomiopathy recorded no evidence of systemic embolism in the group treated with anticoagulants, whereas an embolism rate of $3.5 \%$ per year occurred in the control group. In the absence of a prospective study regarding antithrombotic therapy in patients suffering from idiopathic dilated cardiomiopathy, this evidence, according to the author, permits a continual prescription of Warfarin, particularly to those with heart failure and atrial fibrillation.

Halperin et al. (14) employ a risk stratification to state the norms of their position as to anticoagulants in cardiopathy. Patients with atrial fibrillation and prior embolism would be considered high risk patients; mitral stenosis or valvular prosthesis would be features of substantial risk patients; patients who experienced extensive prior post-infarction and decompensated dilated cardiomiopathy would be intermediate risk subjects. It is 
believed that there is enough evidence for indicating the use of anticoagulants for these groups of patients.

Some patients with atrial fibrillation would also benefit from Warfarin therapy, but its utilization by subgroups is questionable. Patients with atrial fibrillation without evident cardiac disease and those patients with chronic aneurysm in the left ventricle, for whom anticoagulant medication is not recommended, would be considered low-risk patients.

When we try to correlate the available data in patients with Chagas' disease, a condition of recognized morbidity and mortality related to thromboembolic phenomena, it is felt that we are not interfering with a fundamental aspect of our patients' prognosis. However, the difficulties in using this type of medication are well known, specially in chagasic patients who have cultural and socio-economical problems. It should be clear, however, that prospective studies should be carried out so that we can assess the real benefits of antithrombotic therapy, its feasibility in our settings and possibly a risk stratification to avoid the use of potentially dangerous drugs in some subgroups of patients. Until we have a definite answer, it seems that the benefits outweigh the risks. That is especially true in that group of patients who have a greater tendency to develop embolic events (table 1).

Aspirin should also be considered as an alternative for patients who are not good candidates since its side effects are less serious and there is no need for frequent blood tests or dose adjustments.

\section{Resumo}

São freqüentes os fenômenos tromboembólicos nos portadores de cardiopatia chagásica crônica. A mortalidade devido a estas complicações está relacionada na maioria dos casos a embolias pulmonares e encefálicas. Diversos estudos anatomopatológicos e clínicos têm permitido evidenciar um subgrupo de pacientes com maior risco: presença de disfunçăo miocárdica grave, fibrilação atrial, lesão apical do ventrículo esquerdo, presença de trombos intracavitários e fenômenos tromboembólicos prévios.

Estudos prospectivos deverão permitir avaliar os reais benefícios dos antitrombóticos nos pacientes chagásicos, sua praticabilidade no nosso meio e provavelmente uma estratificação do risco, de modo a evitar o uso de drogas potencialmente perigosas em certos subgrupos de doentes. Até que não tenhamos uma resposta definitiva, parece que os beneficios desse tipo de terapia excedem os riscos, principalmente para aquele grupo com maior propensāo aos eventos embólicos. 


\section{REFERENCES}

1. ALBANESE FILHO, F.M. \& GOMES, J.B. - O tromboembolismo em pacientes com lesão apical da cardiopatia chagásica crônica. Rev Port Cardiol 10:35-42, 1991.

2. ANDERSON, R. - Mediator of inflammation and tissue damage. South Africa Med 62:365-9, 1982.

3. ANDRADE, Z.A. \& ANDRADE, S. - A patologia de doença de Chagas. Bol Fund Gonçalo Moniz 6:1-52, 1955.

4. ANDRADE, Z.A. \& SADIGUSKY, M. - Tromboembolismo em chagásicos com insuficiência cardíaca. Gaz Med Bahia 71:59-64, 1971.

5. ARTEAGA-FERNANDEZ, E.; BARRETO, A.C.P.; IANINI, M.B. et al. - Trombose cardíaca e embolia em pacientes falecidos de cardiopatia chagásica crônica. Arq Bras Cardiol 52:189-92, 1989.

6. CARVALHO, J.A.M. - Tromboembolismo da doença de Chagas em Pernambuco. Considerações em torno da incidência em material necroscópico. Rev Bras Doenças Trop 15:611-6, 1963.

7. CATAGNINO, H.E.; CICCOS, J.A.; FAUTH, M. et al. Miocardiopatia emboligena en la enfermedad de Chagas. Medicina 38:35-9, 1978.

8. DE MORAIS, C.F.; HIGUCHI, M.L. \& LAGE, S. - Chagas' heart disease and myocardial infarct. Incidence and report of four necropsy cases. Ann Trop Med Parasitol 83:207214, 1989.

9. ELIAN, A.A. - Aspectos clínicos do tromboembolismo. In: Cançado, S.R. \& Chuster, M. - Cardiomiopatia Chagásica. Belo Horizonte: Fundação Carlos Chagas 1985. p. 31422.

10. FERNANDES, S.O.; OLIVEIRA, M.S.; TEIXEIRA, V.P.A. \& ALMEIDA, H.O. - Trombose endocárdica e tipo de lesão vorticilar esquerda em chagásicos crônicos. Arq Bras Cardiol 43:17-9, 1987.

11. FUSTER, V.; GERSH, B.J.; GIULIANI, E.R.; TAJIK, A.J.; BRANDEMBURG, R.O. \& FRYE, R.L. - The natural history of idiopathic dilated cardiomyopathy. Am J Cardiol 47:52331, 1981.

12. GOLDHABER, S.Z. \& SORS HERVÉ - Treatment of venous thrombosis and pulmonary embolism. In: Fuster, V. \& Verstraete, M. eds. Thrombosis in cardiovascular disorders. Philadelphia, W.B. Saunders Company, 1992. p. 465-83.

13. GOLDMAN, S.; JOHSON, G.; COHN, J.et al. - Mechanism of death in heart failure. The vasodilator-heart failure trial. Circulation 87: V124-V131, 1993.

14. HALPERIN, J.L. \& PETERSEN, P. - Thrombosis in the cardiac chambers: ventricular dysfunction and atrial fibrillation. In: Fuster, V. \& Verstraete, M. eds. Thrombosis in cardiovascular disorders. Philadelphia: W.B. Saunders Company, 1992. p. 465-83.

15. HYERS, T.M. - New diagnostic and therapeutic strategies in venous thromboembolic disease. In: Taylor, R.W. \& Shoemaker, W.C. eds. Critica care. State of the art. Fullerton. Society of Critical Care Medicine 1991. 255 p.

16. KOBERLE, F, - Patologia e anatomia patologica de la enfermedad de Chagas. Bol Ofic Samit Panam 51:404-28, 1961.

17. MASON, R.G.; MOHAMMAD, S. \& SABA, H.I. - Function of endothelium. Pathobiol Ann 9:1-4, 1979.

18. MIGNONE, C. - Alguns aspectos da anatomia patológica da cardite chagásica crônica. São Paulo, 1958 [Tese catedrático - Faculdade de Medicina da USP. São Paulo, Universidade de São Paulo].

19. NEIVA, A.R. \& ANDRADE, Z.A. - Embolia cerebral em portadores de miocardite crônica chagásica. Hospital 61:3739, 1962.

20. NUSSENZWEIG, I.; WALEHEMBERG, B.L.; MACRUZ et al. - Acidentes vasculares cerebrais embólicos na cardiopatia chagásica crônica. Arq Neuropsiquiatr 11:307$402,1953$.

21. OLIVEIRA, J.M.S. - Tromboses cardíacas e tromboembolismo. In: Cançado, S.R. \& Chuster, M. Cardiomiopatia Chagásica. Belo Horizonte: Fundação Carlos Chagas, 1985.

22. OLIVEIRA, J.S.M.; ARAÚJO, R.R.C.; NAVARRO, M.A. \& MUCILLO, G. - Cardiac thrombosis and thromboembolism in chronic Chagas' heart disease. Am J Cardiol 52:147-51, 1983.

23. PERTERSEN, P. \& GOSSELINK, M. - Antithrombotic therapy in nonvalvular atrial fibrillation: What are the benefits? Contovesies in Cardiology 3:7-9, 1991.

24. PORTO, C.C. \& RASSI, S. - Formas clínicas de cardiopatia chagásica crônica. Arq Bras Cardiol 2:235-7, 1989.

25. RASO, P.; CHAPADEIRO, E.; TAFURI, W.L.; LOPES, E.R. \& ROCHA, A. - Anatomia patológica da cardiopatia crônica. In: Cançado, S.R. \& Chuster, M. - Cardiomiopatia Chagásica. Belo Horizonte: Fundação Carlos Chagas, 1985. p. 41-53.

26. ROCHA, H.P. \& ANDRADE, Z.A. - Fenômenos tromboembólicos pulmonares em pacientes portadores de miocardite crônica chagásica. Arq Bras Cardiol 45:355-9, 1955.

27. SILVA, B.A.; MARINS, N.; KAGAMI, S.K.; SILVA, C.T.; MOTTA, V.P. \& BARBOSA, P.H. - Acidentes cerebrovasculares tromboembólicos e miocardite chagásica. Arq Bras Cardiol 432:45-9, 1979.

28. SINGER, D.E. - Randomized trials of warfarin for atrial fibrillation. N Engl J Med 327:1451-3, 1992.

29. SOBRAL NETO, J.; DUARTE, L.C.A.; BRESSANE, J.F; MATTOS, J.V.; MIZIARA, H.L. \& MARINS, N. Tromboembolismo na cardiopatia crônica. Arq Bras Cardiol 30:209-14, 1977. 